Cursor_Zeitschrift für explorative Theologie

\title{
Digital theology: A proposal and the need for diverse voices
}

\section{Stephen Garner}

Published on: Nov 06, 2020

DOI: $10.21428 / \mathrm{fb} 61 \mathrm{f} 6 \mathrm{aa} .76 \mathrm{c} 476 \mathrm{~d} 1$

License: Creative Commons Attribution 4.0 International License (CC-BY 4.0). 


\section{Introduction}

Christian theology is the activity of individuals and faith communities seeking to understand both the Christian faith and the object of that faith, the Triune God. Theology can be confessional, shaped by creeds and confessions; it can be liturgical, expressed in the worshipping life of the church; it can be contextual, lived out in a dialog between the experience of the world and reflection on the Christian faith; and it can be public, both in terms of mission and evangelism, as well as seeking to serve the polis first and the ekklesia second. Many other forms of theology are possible too, and into this complex mix of theologies and communities emerges the term "digital theology," which is caught up in the Christian community's grappling to understand and live out the Christian faith in a world in which we are wrapped in media and colonized by technology.

The focus of this article is two-fold. Firstly, it will offer some thoughts on what an integrated digital theology might look like, along with a modest proposal for that. Secondly, it will ask that if we are serious about doing theology in digital contexts, and we see those digital contexts as bringing all parts of the world together, then whose voices are not at the table for this discussion. In these discussions are we informed by those from Africa, Asia, Latin America, Oceania, and others in our own locations who are all also affected and present in our digital worlds? Those voices are essential for digital theology to reflect the fullness and richness of the body of Christ, and so that we don't create an understanding of digital theology that colonizes, oppresses, and marginalizes those in both faith and wider communities who are also caught up in this increasingly ubiquitous digital world. It is my contention that fruitful dialog with these other communities will help point out the "planks in our own eyes« that we might be oblivious to.

\section{Digital Religion}

Digital theology stands in continuity with, and is indebted to, the more established field of digital religion. At times they overlap, but mostly they are distinct with the most significant differences coming firstly in the form of theological or faith commitments and, secondly, in the methodologies and disciplines used. Digital religion is primarily concerned with how religion in its various forms engages with, is shaped by, and is present in digital culture and media. As such, its primary modes of study tend to be shaped by anthropology, sociology and communications and media studies. While those involved in digital religion may have their own faith commitments, the primary location for studying religion in digital spaces is from the outside looking in. 1 That said, the insights brought by this discipline inform and shape the theological engagement with digital cultures of those on the inside of religious communities or traditions. 
Chris Helland's now classic distinction between religion-online and online-religion is a good example of this kind of outside-in approach. $\stackrel{2}{2}$ While the religion-online/online-religion distinction can be overly simplistic at times, the recognition that religious communities extend themselves into digital spaces (religion-online), replicating their physical ecclesiology and organization in virtual spaces, as well as those who experience or form new kinds of religious or spiritual experiences (online-religion) in those same spaces is helpful for theological communities thinking about their own notions of ecclesiology, personhood, authority and community. Similarly, Tim Hutchings work investigating how different Christian church communities shape their lives in engagement with virtual spaces is a development along the lines of religion-online. $\underline{3}$ Rachel Wagner's significant work looking at the formation and power of ritual in virtual spaces enriches the theological discussion in regard to the location and construction of culture and meaning religiously and spiritually in online spaces, even if people are not always aware that they are doing so. $\underline{4}$

Digital religion also provides the theologians and their communities with helpful tools for selfreflection on the use of digital and media culture in those communities. Heidi Campbell's religioussocial shaping of technology is one such analytical tool allowing those both inside and outside of religious communities to examine how technology and media are negotiated socially through an historical trajectory. $\underline{5}$ Attention is paid to how technology and media have been adopted in the past by a community; the core values, beliefs and practices that shape the life of the community; the ways in which a community negotiates the adoption of technology and media; and the ongoing internal negotiation by the community of how an adopted technology is used provides a helpful tool for both outsiders seeking to understand a faith community's relationship with media and technology, as well as insiders performing with their own critical self-reflection around the same matters.

For example, the religious-social shaping of technology might be used to examine how Amish communities work out an ethic of appropriate technology. The impact of technologies upon community life is a key criterion, and the appropriateness of a technology for the community then defines its location within the community. Reflection upon previous negotiated technologies, the core values of the community concerning family, community, and faith, and the ongoing negotiation of adopted technology within and between Amish communities using the framework provides helpful insight for both those within the communities and those outside to understand how that adoption does or does not occur. Examples of these include the utility of telephones, both landline and mobile, in for emergencies and in work is recognised and so they are placed where people can access appropriately for the wellbeing of the community, as well as advanced genetic therapy research that has the potential to help certain conditions endemic to their population and has received Amish funding and support. $\underline{6}$ 
Similarly, the work performed in digital religion concerning the negotiation and impact of forms of religious media, such as sacred texts like the Christian Bible, also feeds back into digital theology. Peter Horsfield's work surveying how historic changes in the media landscape over the history of Christianity has shaped both that faith and its interaction with media provides a valuable resource for the theological community, especially when thinking about didactic and revelatory contexts. $\frac{?}{}$ Horsfield's work highlights the complex and often symbiotic relationship between religion and media and how developments in each affects the other.

Moreover, there is a developing overlap between digital religion and digital theology, and those in both fields interact through scholarly and practical contexts. The book Networked Theology provides an example of what this might look like when communications studies and theology engage each other to develop a framework for Christian faith communities to think more deeply about the digital media culture they are embedded in. $\underline{8}$ Drawing on both disciplines, the outcome is a project that connects to faith communities in terms relevant to their context, as well as highlighting how digital religion resources might inform and resource the communities they are typically studying. Explanations of theoretical frameworks for understanding digital technologies and new media are provided, as well as reflection on Christian responses to media and technology, leading to an integrated approach for engaging wisely and appropriately with technology and media using the religious language and symbols of Christian communities supported by both theology and communications studies in dialogue.

\section{Theology as distinct activity}

Christian theology, as noted previously, is the activity of the Christian community as it seeks to deepen its understanding of its faith and the object of that faith. Pete Phillips et al take a particular definition of theology and then explicitly use that understanding to underpin their reflection on the emerging discipline of digital theology. $\stackrel{-}{ }$ Differing from the related field of digital religion, which they see as more focused on the phenomena of religion in digital culture and a sociological analysis of that, digital theology takes as its starting point the assertion the theology is »the critical study of the nature of God, or of God's interaction with the world, or of the world's exploration of the mystery of faith. «은 For Phillips et al, digital theology represents four different but related categories: mediated education; digitally-enabled research; theologically-resourced engagement with digital culture; and theological ethical engagement with digital technology and culture. It is the latter two categories that this article is focused upon, but it is important to sketch the first two categories briefly.

The initial category, that of didactic digital theology, occurs when digital technologies mediate the instruction of theology, typically as part of formal academic study where the discipline provides the content and technology provides the communication mode. This category is also broad enough to include things like didactic mobile applications and video games which seek to educate the faithful 
through digital media, as well a use of digital media for storytelling, photography, and broader Christian formation. $\underline{11}$

The second category identifies digital theology as theological research carried out through digital technology, media, and culture, where research moves from individual engagement with primarily physical texts to collaboration with widespread networks of researchers, working with flexible digital facsimiles of physical texts, as well as data analysis and visualization, and engagement with online religious practices. However, as Neele comments, researching in these modes is an ongoing negotiation involving the acquisition of new digital skills, different forms of access to texts and data, and working out how to best connect different digital resources to give new insights. Neele's reflection on digitallysupport theological research in relation to the works of John Calvin draws this conclusion:

In conclusion, the current developments in the digital landscape, including the field of theology, and in particular those related to the studies of Calvin's work by a continuing and increasing number of available primary sources, as well as a rising number of possibilities of making use of these sources, offer at the same time various opportunities and limitations, as the boundaries of scholarship, open access and commercial interest will continue to be tested, appropriated and defined.

...

The field of theology should make discriminated use of the new possibilities of digital research, education and publication to raise academic standards by internationally advancing thoughtful theological reflections through digital media. $\underline{12}$

The third category of digital theology, and the primary one this paper is concerned with, considers digital culture as the context in which theology is done. Here there is a genuinely reflexive dialog between digital culture and theology, where theology offers guiding principles related to participation in digital culture and digital culture offers guiding principles by which we participate in theology. This resonates with the definition of contextual theology put forward by missiologist Stephen Bevans that describes theology as an ongoing theological process of bringing the experience of the past found in the Church's Scripture and Tradition into genuine dialog with the experience of the present. $\underline{13}$ This experience of the present is located primarily in social locations shaped by factors such as gender, age, ethnicity, socioeconomics, health, and power.

In this form of contextual digital theology, the experience of the present embraces the digital world we find ourselves in, raising questions and possibilities for theological engagement. This in turn connects to the final category of digital theology, which extends the third category by adding a theological-ethical critique of digital technology and culture, which appraises digital cultures strengths and weaknesses as they relate to individual and communal human flourishing and well-being. A good 
example of this latter category is Nadia Delicata's work on the role of natural law for thinking and acting ethically in digital contexts and which highlights how theological ethics might supply wisdom in a culture of content-creation and making and the work by Garner on evaluating ethical frameworks in digital spaces with a view to, in a similar fashion to Delicata, creating a kind of phronesis or practical wisdom. $\underline{14}$

\section{Integrated Digital Theology}

While we might talk about digital theology as an emerging discipline, activity in each of the four categories above has been underway since the 1970s in theological communities seeking to understand how to engage with and live wisely within digital contexts. What would be fair to say though, is that, with some notable exceptions, most theological engagement with digital technology and media has been in specific areas of interest and not necessarily integrated across the breadth of life and faith. For example, there are those who are focused particularly on ecclesiology - the theology of the church asking questions about how social media and digital communications might change how the church might think about being the body of Christ in a digital world and wrestling with the impact of the digital context on the institution of the church and things like the church's authority structures. $\underline{15}$

For others, it is the nature of sacraments in digital spaces and what worship looks like in those spaces, while interests in discipleship - the life and faith of individual believers and communities - spin out into mission and evangelism. $\underline{16}$ Media and entertainment such as video games and faith are another location of engagement, as well as others who are thinking about how our interaction with digital devices and culture changes the ways we expect to be able to manipulate and experience faith, life, prayer, the Bible, preaching, and our engagement with our wider communities. $\underline{\underline{17}}$

What each of these different engagements offer are vignettes of theology and digital contexts intersecting in different ways. What is missing, but not exclusively so, are attempts to develop integrated frameworks that provide robust ways of engaging with the breadth of Christian theology in dialog with digital technology and culture rather than just one particular aspect typically, but not always, investigated in purely pragmatic ways. What we need to seek are deep, reflective, and consistent ways of engaging with the range of digital contexts and experiences, including those that have not yet become apparent.

The World Council of Churches' Shifting Realities book and the Roman Catholic Church's Church and Internet document from the late 1990s and early 2000 s respectively were initial attempts to commence this kind of integrative venture. $\underline{18}$ Subsequently, we have seen the emergence of other more integrative works in this area including Antonio Spadaro's, Cybertheology, Andy Byers, TheoMedia, and Heidi Campbell and Stephen Garner's, Networked Theology. $\underline{19}$ 
In the case of the latter, the dialog between the two authors, a communications scholar and a theologian, draws from both digital religion as well as theological reflection on biblical texts of such as Micah 6.8 - do justice, love kindness, and walk humbly with God - and Jesus' »Parable of the Good Samaritan« (Lk 10,25-37) to develop a framework asking how doing justice, loving your neighbour, and honouring God might be lived our in digital and media cultures. It is a starting point for doing digital theology, being sketched around these broad questions, but further work developing more detailed and deeper theological engagement building on this and other attempts will be needed.

So, what then might an integrative digital theological look like? A digital theology that engages the different interests and questions that people have about faith and digital culture intersecting and weaving those together in a way that draws upon the richness of Scripture and Tradition and develops a robust engagement in different areas using a common theme or framework.

My modest proposal is that this kind of digital theology should draw together a number of the traditional areas from systematic theology, as well as key topics from pastoral and practical theology, and then bring those things into dialog with the digital context using an integrative theme. One such theme might be the theme of hope, and in particular, the Christian hope that is woven through creation and new creation, human technological agency, the person and work of Jesus Christ, visions of human flourishing and community, as well as personal formation and transformation. It also intersects with our narratives of technological hope and salvation, common ground in visions for human flourishing and ecological sustainability and makes us aware of where human technological agency has marginalized people and left them 'hope-less'. Eschatological hope also provides an ethical dimension, raising our eyes from what is present to what might be on the other side of the eschaton and drawing us into agency that reflects the new creation. As Robert Russell puts it:

It is this eschatological future-no matter how dim, how inconceivable it is in light of science, no matter how unlikely it is in light of evil and suffering in human society and nature - to which we must orient all out ultimate plans and ideals and convictions if we are to live as Christians today in the Easter dawning of a new age. $\underline{20}$

Starting with the theme of Christian hope, this digital theology brings together theological areas such as revelation, including biblical engagement; creation - the world, human agency, and new creation; theological anthropology; Christology; soteriology — sin and salvation; community - ecclesiology and wider human society; and discipleship and faith formation and asks how to we reflect on those things in light of living in a world where we're wrapped in media and colonized by technology. What might an integrated digital theology of hope have to offer, not just to the church, but in offering something distinctive, robust, hopeful and gospel to the wider world and its digital contexts?

\section{Missing voices}


And as we contemplate how we might shape this emerging field of digital theology another significant question needs to be asked. If digital media and communications are part of a globalizing force bringing together different cultures, places, and people, does our articulation of digital theology genuinely reflect that? If we look back over the people and resources mentioned in the previous sections, they all come from the UK, Europe, North America and Australasia. Is digital theology to be shaped, informed, or responsive to local cultural expression within the global context or does it simply mean the assimilation of all other theological and cultural perspectives and insights into a homogenized Western theological framework with its own priorities? Are the insights that might be brought from Asian, African, Latin American, and Oceanian cultures concerning notions of space, communication, relationality, and so on, simply to be ignored and those cultures and peoples left outside of this conversation?

My own theological research is increasingly informed by these missing voices and I have been privileged to have worked with Māori (the indigenous people of Aotearoa New Zealand) and Pacific Island colleagues and graduate students from whom I continue to learn. In the following section there are several examples of this in relation to digital theology. Two are from Māori Anglican priests who are postgraduate students of mine and one from the wider Pacific context. I do not speak for them, but rather offer what they have reflected on and which has informed my own work. $\underline{21}$

Zhane Rawiri Tahau Whelan (Ngāti Kahungunu \& Ngāti Tūwharetoa) explored whether a Māori, and particularly a Māori Christian, understanding of our world offered something to both Maori and other communities about a relationality that informed and shaped wise and wholesome engagement with social media. Drawing upon the work of Māori Catholic theologian, Henare Tate, who developed a framework for maintaining whanaungatanga (right and lifegiving relationships) based on the threeway relationship between Atua (God), tangata (people), and whenua (the land). $\underline{22}$

This three-way relationship is mediated by tapu (restrictions) that is located in tika (the right and appropriate ways of maintaining relationships), pono (fidelity, truthfulness, integrity) and aroha (love, empathy, compassion or joy). Whelan extended this model from a physical location (whenua) into the shaping of behaviour in social media to maintain right and healthy relationships (whanaungatanga). His insight provided an interesting and helpful counternarrative to the individualistic use of social media through the valuing of others encountered in digital spaces.

Similarly, Michael Tamihere (Ngāti Porou) considers how one might develop tikanga (the right and appropriate way of doing things) in relation to live digital streaming of Māori tangihanga (funerals) to those who cannot be physically present. This involves a negotiation between the local tikanga of the respective community, the tikanga of Te Hāhi Mihinare (the Māori Anglican Church), and the particular digital media in question to find a way forward that is both respectful to the local community and 
enabling for those who cannot travel to the tangi to be present in some way. Again, right and appropriate relationships lie at the heart of creating the tikanga for doing this.

In a broader Pacific context, Cresantia Koya-Vaka'uta considers the notions of the va or relational space present within Samoan and Tonga communities and how this relational space might translate into the context of social media. $\underline{23}$ The $v a$ is both simple and complex, providing a framework for understanding how things relate to each other in the world, shaping identities as well as social engagement between people. Digital media challenges and reshapes the notion of space, place and time which impacts upon traditional understandings of the $v a$, including religious and spiritual dimensions of that found in the va tapuia (Samoa) and teitapu (Tonga). In thinking about the way online digital media reshapes understandings of space and time, she notes that:

Tausi Ie Vā (Samoa) and Tauhi Vā (Tonga) carry with them beliefs and attitudes towards the cultural values of compassion, respect, reciprocity, restrained behavior, service, love, humility, wisdom, patience and unity. These values imbue the manner in which relationships play out in the socio-cultural context. It is significant in the Samoan and Tongan cultural space-time continuum that cultural relationships which were once solely nurtured and maintained in 'physical geographical place and real time' are now enabled through 'cyberspace' in cyber-place and cyber-time. $\underline{24}$

Voices such as Whelan, Tamihere and Koya-Vakauta contribute ways of thinking about and living well in digital culture that serve several purposes. It can add a richness to our theological engagement with digital media drawn from cultural and geographic diversity within the church; it can prompt us to rethink our own engagement with digital media and culture; and it serves as a reminder that no one group has priority in defining the field of digital theology. The modest proposal presented earlier would benefit from other, different eyes looking at it, weighing it up, and offering critique.

This raises the question of how might something like Tate's understanding of maintaining whanaungatanga or right relationships and mediated through Pacific theologies with their relational and communal dimensions speak into the globalizing digital media and Western constructions of digital theology? Can we create digital theology, or perhaps digital theologies, that engage a postcolonial world with both local and global holistic frameworks, and what might that offer to our Western culture and our theological reflections on digital culture? There is no way to answer these questions if we do not have others different from ourselves around the table.

\section{Conclusion}

As digital theology emerges as a distinct discipline it is faced with many choices about the way ahead. It can continue, much as it has, and generate various important, but niche, projects and investigations 
around doctrines, technologies, and issues or concerns that arise. It might divert some of its energy into developing integrated frameworks that bring multiple parts of Christian theology together in constructive dialog with digital culture, helping to systematize and coordinate those various individual projects.

The latter will be important for digital theology to generate its own methodologies and approaches to doing theology in digital contexts, much as the field of digital religion is stronger for the development of its own theoretical approaches as it has matured. It also remains to be seen if the distributed nature of digital culture will encourage and enable genuine ecumenical collaboration within the field, or whether traditional theological silos continue to be maintained.

Finally, one of the key challenges for digital theology will be to engage with a range of voices from around the world and in local communities, listening humbly to those, and not simply creating digital theologies that ignore the richness of the body of Christ in order to maintain traditional power structures.

\section{Footnotes}

1. Heidi Campbell, "Surveying Theoretical Approaches within Digital Religion Studies," New Media \& Society 19, no. 1 (2017): 15-24.

2. Christopher Helland, "Online-Religion/Religion-Online and Virtual Communitas," in Religion on the Internet: Research Prospects and Promises, ed. Douglas E. Cowan and Jeffrey K. Hadden (New York: JAI, 2000), 205-23.

3. Tim Hutchings, Creating Church Online: Ritual, Community and New Media, Routledge Research in Religion, Media, and Culture (New York: Routledge, Taylor \& Francis Group, 2017). $\subseteq$

4. Rachel Wagner, Godwired: Religion, Ritual, and Virtual Reality, Media, Religion, and Culture Series (Abingdon, Oxon ; New York: Routledge, 2012).

5. Heidi Campbell, When Religion Meets New Media (London ; New York: Routledge, 2010), 50-59.

6. Katie Engelhart, "Amish Opening up to Modern Tech in Some Communities," NBC Universal, https://www.nbcnews.com/leftfield/video/amish-opening-up-to-modern-tech-in-some-

communities-1178374723793; Harmeet Kaur, "No One Knew Why the Kids in 2 Amish Families Were Dying Suddenly. Now Researchers Have Some Answers.," Cable News Network (CNN), https://edition.cnn.com/2020/01/16/health/amish-children-sudden-deaths-mysterytrnd/index.html; Bill McKibben, Enough: Staying Human in an Engineered Age (New York: Times Books, 2003), 166-68; Kevin D. Miller, "Technological Prudence: What the Amish Can Teach Us," Christian Reflection: A Series in Faith and Ethics (2011): 20-23. 
7. Peter G. Horsfield, From Jesus to the Internet : A History of Christianity and Media (The Atrium, Southern Gate, Chichester, West Sussex , UK ; Malden, MA: John Wiley \& Sons, Ltd, 2015). 8. Heidi Campbell and Stephen Garner, Networked Theology: Negotiating Faith in Digital Culture (Grand Rapids: Baker, 2016). $\doteq$

9. Peter Phillips, Kyle Schiefelbein-Guerrero, and Jonas Kurlberg, "Defining Digital Theology: Digital Humanities, Digital Religion and the Particular Work of the Codec Research Centre and Network," Open Theology 5, no. 1 (2019): 29-43. 10. "Defining Digital Theology: Digital Humanities, Digital Religion and the Particular Work of the Codec Research Centre and Network," 37.

11. Mary Hess, Engaging Technology in Theological Education: All That We Can't Leave Behind, Communication, Culture, and Religion Series (Lanham, MD: Rowman \& Littlefield Publishers, 2005); Mary E. Hess, "A New Culture of Learning: Digital Storytelling and Faith Formation," Dialog: A Journal of Theology 53, no. 1 (2014): 12-22; Eileen D. Crowley, "“Using New Eyes": Photography as a Spiritual Practice for Faith Formation and Worship," Dialog 53, no. 1 (2014): 30-40; Jason Anthony, "Dreidels to Dante's Inferno: Toward a Typology of Religious Games," in Playing with Religion in Digital Games, ed. Heidi Campbell and Gregory P. Grieve (Bloomington: Indiana University Press, 2014), 25-46; Stephen Garner, "Imaging Christ in Digital Worlds: Continuity and Discontinuity in Discipleship," Communication Research Trends 38, no. 4 (2019): 321-30; Aline Amaro da Silva, "Catechesis in the Digital Age: From Transmission to Sharing," Communication Research Trends 38, no. 4 (2019): 11-20; Kyle Matthew Oliver, "Networked Religion Meets Digital Geographies: Pedagogical Principles for Exploring New Spaces and Roles in the Seminary Classroom," Teaching Theology \& Religion 22, no. 1 (2019): 3-15.

12. A.C. Neele, "Research in Theology in the Digital Age: Opportunities and Limitations.," Acta Theologica 31, no. 2 (2011): 195-96.

13. Stephen B. Bevans, Models of Contextual Theology (Maryknoll: Orbis Books, 2002), 3-9. 14. Nadia Delicata, "Natural Law in a Digital Age," Journal of Moral Theology 4, no. 1 (2015): 1-24; Stephen Garner, "Duties, Consequences or Virtues? Theological Ethics for Social Media," in Theologische Medienethik Im Digitalen Zeitalter (Theological Media Ethics in the Digital Age), ed. Gotlind Ulshöfer and Monika Wilhelm (Stuttgart: Kohlhammer-Verlag, 2020), 187-203. $\subseteq$ 15. Miriam Diez Bosch et al., eds., Authority and Leadership: Values, Religion, Media (Barcelona: Ramon Llull University, 2017); Douglas Estes, Simchurch: Being the Church in the Virtual World (Grand 
Rapids, Mich.: Zondervan, 2009); Dwight J. Friesen, Thy Kingdom Connected: What the Church Can Learn from Facebook, the Internet, and Other Networks (Grand Rapids: Baker Books, 2009). 16. Sacraments, church and worship: Susan White, Christian Worship and Technological Change (Nashville: Abingdon Press, 1994); Daniella Zsupan-Jerome, "Virtual Presence as Real Presence?: Sacramental Theology and Digital Culture in Dialogue," Worship 89, no. 6 (2015): 526-42; Heidi Campbell, The Distanced Church: Reflections on Doing Church Online, (College Station, TX: Digital Religion Publications; Texas A\&M University, 2020), https://oaktrust.library.tamu.edu/handle/1969.1/187891. Discipleship and mission: Philip R. Meadows, "Mission and Discipleship in a Digital Culture," Mission Studies: Journal of the International Association for Mission Studies 29, no. 2 (2012); Kyle M. Oliver and Stacy Williams-Duncan, "Faith Leaders Developing Digital Literacies: Demands and Resources across Career Stages According to Theological Educators," Journal of Media Literacy Education 11, no. 2 (2019): 122-45; Garner, "Imaging Christ in Digital Worlds: Continuity and Discontinuity in Discipleship," 21-30. 17. Anthony, "Dreidels to Dante's Inferno: Toward a Typology of Religious Games," 25-46; Daniel White Hodge, "Role Playing: Towards a Theology of Gamers," in Halos and Avatars: Playing Video Games with God, ed. Craig Detweiler (Louisville, Ky.: Westminster John Knox Press, 2010), 163-75; D. Brent Laytham, Ipod, Youtube, Wii Play: Theological Engagements with Entertainment (Eugene, Or.: Cascade Books, 2012); Crowley, "Using New Eyes," 30-40; Stephen Garner, "Are You My Neighbor? Theology, Networks, and Encounters with God and Others," in Authority and Leadership: Values, Religion, Media, ed. Miriam Diez Bosch, et al. (Barcelona: Ramon Llull University, 2017), 111-22; Hess, "A New Culture of Learning: Digital Storytelling and Faith Formation," 12-22; Peter Phillips, "The Pixelated Text: Reading the Bible within Digital Culture," Theology 121, no. 6 (2018): 403-12. 18. David Lochhead, Shifting Realities: Information Technology and the Church (Geneva: WCC Publications, 1997); Pontifical Council for Social Communications, "The Church and Internet," http://www.vatican.va/roman_curia/pontifical_councils/pccs/documents/rc_pc_pccs_doc_20020228 _church-internet_en.html. $\triangleq$

19. Antonio Spadaro, Cybertheology: Thinking Christianity in the Era of the Internet, trans. Maria Way (New York: Fordham University Press, 2014); Andrew J. Byers, Theomedia: The Media of God and the Digital Age (Eugene, Oregon: Cascade Books, 2013); Campbell and Garner, Networked Theology: Negotiating Faith in Digital Culture. 20. Robert J. Russell, "Five Attitudes toward Nature and Technology from a Christian Perspective," Theology and Science 1, no. 2 (2003): 157. 
21. I deeply appreciate the generosity of Zhane Whelan and Michael Tamihere in allowing me to share something of their work in this article. $\doteq$

22. Henare Tate, He Puna Iti I Te Ao Marama = a Little Spring in the World of Light (Auckland, N.Z.: Libro International, 2012).

23. Cresantia Frances Koya-Vaka'uta, "The Digital Va: Negotiating Socio-Spatial Relations in Cyberspace, Place and Time," in The Relational Self : Decolonising Personhood in the Pacific, ed. Upolu Luma Va'ai, Unaisi Nabobo-Baba, and Pacific Theological College. (Suva, Fiji: University of the South Pacific Press, 2017), 61-78.

24. "The Digital Va: Negotiating Socio-Spatial Relations in Cyberspace, Place and Time," 68. 